\title{
LHX3 Gene
}

National Cancer Institute

\section{Source}

National Cancer Institute. LHX3 Gene. NCI Thesaurus. Code C104955.

This gene encodes a transcription factor that plays a role in both pituitary development and motor neuron specification. 